Ronaldo Manoel Silva'

'Universidade Federal Rural de Pernambuco, Recife, PE, Brasil

\title{
Clara Fernandes, uma lésbica perante o Tribunal da Inquisição (1555-1560)
}

Resumo: Na sociedade portuguesa de Antigo Regime, o sexo entre mulheres era suscetível à pena de morte na fogueira e, por ser um crime de foro misto, também esteve sob a alçada do Tribunal da Inquisição. O objetivo deste estudo é analisar o processo inquisitorial da jovem Clara Fernandes, sentenciada em 1556 por sodomia foeminarum. Apesar de casada e mãe de três filhos, as atitudes de Clara externam um incontido desejo sexual por mulheres. Atormentada por suas "culpas", buscou o perdão do Santo Ofício, mas encontrou a "justiça" de um Tribunal inclemente.

Palavras-chave: Inquisição: sodomia foeminarum; repressão

\section{Introdução}

É o homoerotismo que encarcera ou o homoerotismo é o motivo do cárcere? Na documentação que iremos analisar, a jovem Clara Fernandes parece ter vivido essa ambiguidade: prisioneira de desejos considerados ilícitos, procurou dar respostas aos seus anseios e, uma vez consumados, teve como pena os cárceres inquisitoriais. Clara foi presa e condenada por crime de sodomia foeminarum que, atualmente, corresponde ao sexo entre mulheres. Segundo Luiz MOTT (1987, p. 8), a história do lesbianismo era uma página em branco, tendo merecido a atenção de alguns estudiosos somente nas últimas décadas. Tal escassez se deve possivelmente à ausência ou insuficiência de fontes sobre o assunto. Mas quais seriam as razões que explicariam esse silêncio das fontes? Especialistas parecem concordar que nas sociedades ocidentais a homossexualidade feminina teria sido mais tolerada ou, pelo menos, mais discreta que a masculina; outros entendem que a importância da história da homossexualidade para a história da sexualidade em geral ainda é uma descoberta do passado recente (Magali ENGEL, 1997, p. 434-435).

\section{(c) (7)}

Esta obra está sob licença Creative Commons. 
Sabemos que a documentação sobre a história do lesbianismo é escassa, fragmentária e, como veremos adiante, muitos registros foram destruídos como consequência da própria misoginia. O termo "lesbianismo" nos remete à Grécia Antiga: à poetisa Safo (c. 612-560 a.C.), natural da ilha de Lesbos. Daí a designação posteriormente dada às lésbicas, sendo que Safo criou e dirigiu um círculo literário de adolescentes de boas famílias, oriundas de todo o mundo helênico. Sob o signo de Afrodite, as jovens poetizavam e musicavam procurando tornarem-se mulheres perfeitas. Safo exaltava em versos seu amor por algumas mulheres. Das muitas composições que redigiu (nove livros, célebres na Antiguidade), apenas uma pequena parte chegou até nós, já que a grande maioria foi destruída no século XI, por ordem do papa Gregório VII, no âmbito da chamada reforma gregoriana (Paulo Drumond BRAGA, 2011 , p. 2-4; Lígia BELLINI, 2014, p. 64-65).

Ainda acerca da terminologia, muito se discute se incide (ou não) em anacronismo utilizar termos como "homossexualidade" e "lesbianismo" para designar uma suposta "orientação da sexualidade" e "conduta homoerótica" das mulheres do passado. Concordamos com Judith BROWN (1987, p. 37-39) e Paulo Drumond Braga (201 1, p. 2) e, fugindo a debates que julgamos estéreis, nos valemos de tais termos por comodidade de linguagem. A bem da verdade, as dificuldades conceituais que os homens da Época Moderna enfrentaram em relação à "sexualidade lésbica" se refletem na falta de uma terminologia adequada. O conceito de "homossexualidade feminina", obviamente, inexistia. Apesar da palavra "lésbica" aparecer uma vez no século XVI, na obra de Brantôme, não foi usada habitualmente até o século XIX. Com a falta de uma nomenclatura adequada e de conceitos precisos, um imenso rol de palavras e eufemismos começou a ser empregado para descrever o que as mulheres supostamente faziam: polução, fornicação, molície, sodomia, depravação mútua, coito, cópula, vício mútuo, violação ou profanação de uma mulher por outra. E aquelas que faziam essas coisas terríveis, se é que mereceriam algum nome, eram chamadas de fricatrices (mulheres que se bolinavam umas às outras) ou tríbades (cf. BROWN, 1987, p. 27-28).

No que concerne à sodomia masculorum, era considerada um pecado abominável desde os antigos hebreus, por serem dois homens a desperdiçarem o esperma, contrariando os alicerces antropológicos de uma família patriarcal onde o varão se orgulhava em demonstrar farta prole. Numa lógica de maximização do aproveitamento do sêmen, o Antigo Testamento praticamente ignorou a ocorrência do lesbianismo dentro do povo judeu (MOTT, 2001, p. 43-45). Já no Novo Testamento, na Epístola aos Romanos, é possível que Paulo tenha se referido a práticas lésbicas - "Por isso, Deus os entregou a paixões vergonhosas: as suas mulheres mudaram as relações naturais em relações contra a natureza" (EPÍSTOLA AOS ROMANOS, 1995, 1, 26).

Exatamente o que o Apóstolo tinha em mente, não é claro. Contudo, Santo Ambrósio (337-397), explicando essa passagem, declarou: "Ele testifica que, estando Deus zangado com a raça humana por causa da idolatria, acontecia de uma mulher desejar outra mulher pelo hábito de vergonhosa luxúria". Também analisando o mesmo versículo, Santo Anselmo (1033-1109) foi categórico: "Assim as mulheres transformaram suas relações naturais em relações antinaturais porque as próprias mulheres cometeram atos vergonhosos com mulheres" (apud BROWN, 1987, p. 15).

De acordo com São Tomás de Aquino (1225-1274), a sodomia era um dos quatro clamantia peccata (pecados que clamam ao céu). No casuísmo inquisitorial, existiam duas maneiras de consumá-la: "perfeita" e "imperfeita". Esta se referia à cópula anal heterossexual; aquela, à cópula anal entre homens. Por sua vez, o sexo entre mulheres (ou sodomia foeminarum) gerou uma complicada discussão na legislação inquisitorial. Se o 
crime consistia na penetração fálica no ânus, com ejaculação intravas, os deputados do Santo Ofício concluíram que, sem pênis, duas mulheres poderiam realizar apenas práticas masturbatórias, que configuravam "pecado de molície" (cf. Carlos FIGARI, 2007, p. 60-63). Molície, conforme esclarece Ronaldo VAINFAS (2014, p. 267, 331), era o nome dado pela teologia moral a vasto elenco de pecados contra natura que não implicassem coito anal: masturbação solitária ou a dois, felação, cunilíngua, penetrações sem ejaculação, gozo nas nádegas, "coxetas", "punhetas", "acessos no vaso traseiro" (conatus), roçar de membros e toda uma plêiade de "torpezas" substitutivas da sodomia.

Quanto às relações sodomíticas entre mulheres, os europeus da Época Moderna tinham uma imensa dificuldade em admitir que as mulheres pudessem realmente se sentir atraídas por outras mulheres. A visão da sexualidade era falocêntrica - as mulheres deveriam se sentir atraídas (apenas) pelos homens e estes, pelas mulheres. Não havia nada numa mulher que pudesse despertar o desejo sexual de outra. Na mentalidade popular, os possíveis casos de lesbianismo eram, na maioria das vezes, ignorados (cf. BROWN, 1987, p. 14). O sexo entre mulheres orbitava entre sodomia e molície e, como veremos adiante, delito de foro misto, suscetível à pena de morte pelo fogo.

\section{Uma legislação repressiva}

De acordo com Raphael BLUTEAU (1638-1734), o termo "nefando" significa "coisa indigna de se exprimir com palavras, coisa da qual não se pode falar sem vergonha". Pecado nefando - o de sodomia - "chama-se o demônio íncubo ou súcubo, de servir ora de homem, ora de mulher, no ato carnal". Enigmático, mas, ao que parece, o enciclopedista "equipara" a sodomia a uma "possessão" demoníaca e conclui que não há registro, em "nenhum autor", de que algum espírito maligno tenha cometido o pecado nefando de sodomia, "prova evidente de que é torpeza tão [grande]", que até ao demônio aborrece (cf. BLUTEAU, 1728). Íncubos e súcubos eram demônios que, respectivamente, assumiam a forma masculina ou feminina para manter relações sexuais com humanos.

Todavia, Bluteau não poderia imaginar que, em 1735, ano após sua morte, a negra forra Maria de Jesus (28 anos), moradora em Lisboa, declararia na Mesa da Inquisição que tinha 12 anos quando foi deflorada pelo demônio. O maligno costumava visitá-la regularmente na forma masculina, "bonito de cara e feio de corpo". Às vezes, o demônio surgia sob a aparência feminina, "tratando torpemente com ela como mulher [...] mostrando ter peitos pequenos e vaso de mulher, como o dela, porém [menor]". Quando o demônio copulava como homem, a negra sentia "dores na parte pudenda". No entanto, quando o maligno sob a aparência de mulher mantinha relações sexuais com Maria de Jesus, ela "não experimentava dor em si, antes deleite" (cf. MOTT, 1988, p. 53). Eis um demônio íncubo e súcubo (por analogia, "bissexual"), proporcionando dor ou prazer à sua atormentada amante.

Quimeras à parte, a primeira condenação à pena capital de uma mulher sodomita na Europa ocorreu em 1477, na cidade germânica de Speyer, onde uma jovem morreu por afogamento (BRAGA, 2011 , p. 9-10). Na França e noutros países europeus, era costume queimar-se junto com o homossexual ou a lésbica o processo que os inculpou, eliminando definitivamente o registro da execução (MOT, 1987, p. 30). Em 1489, o Tratado de Confisson publicado em Chaves (Portugal) determinava que as praticantes de sodomia foeminarum, caso utilizassem algum instrumento penetrante na parceria, à guisa de falo, deveriam passar sete quaresmas em jejum (Verônica de Jesus GOMES, 2015, p. 68). A 20 de dezembro de 1499, respondendo a dúvidas de letrados se as penas aplicadas aos sodomitas cabiam às nefandas, D. Manuel determinou que os juízes civis deveriam aplicar a pena capital à 
mulher "que com mulher usava torpemente como homem" e àquela "que consente como mulher" (BELLINI, 2014, p. 86). Ou seja, cabia pena de morte na fogueira às íncubas e súcubas (ativas e passivas) na relação sexual.

Sempre em Portugal, as Ordenações Manuelinas (1512) e, em seguida, as Filipinas (1603), confirmaram a pena de morte pelo fogo às mulheres que "umas com as outras" praticassem sodomia, "para que nunca de seu corpo e sepultura possa haver memória". No Sacro Império Romano Germânico, a Constituição de 1532, de Carlos V, determinava: "Se alguém comete atos impuros com um animal, ou um homem com um homem, ou uma mulher com uma mulher, perde o direito à vida e deve, segundo o costume habitual, ser sentenciado à morte na fogueira" (BROWN, 1987, p. 23). Crudelíssimo era o castigo previsto na Lei de Treviso, cidade próxima a Veneza, em 1574. A nefanda deveria ser conduzida "amarrada e desnuda" pelas ruas e ficaria exposta por três dias e três noites para, só depois, ser queimada fora da cidade (BRAGA, 2011, p. 9).

No que toca ao Santo Ofício português, as mulheres sodomitas só foram efetivamente mencionadas no Regimento de D. Francisco de Castro (em 1640). Determinava o Regimento que se alguma mulher fosse "compreendida no crime de sodomia", ouviria sua sentença na sala da Inquisição, "pelo grande escândalo, e dano, que pode resultar de se levarem a Auto público semelhantes culpas" e, em seguida, seria degredada para a llha do Príncipe, São Tomé ou Angola. Entretanto, se por razões particulares, conviesse ouvir sua sentença em público, deveria também ser açoitada antes do degredo.

A previsão regimental de punição às mulheres nefandas desencadeou uma laboriosa discussão na cúpula do Santo Ofício. Já em 1644, a Mesa de Goa questionou ao Conselho Geral: "Pode a Inquisição proceder contra mulheres que umas com as outras tiverem cópula e atos sodomíticos, íncubas ou súcubas, [...] com instrumento ou sem ele, por vias anteriores ou posteriores?". Reunidos em Évora para discutir a questão, a maioria dos inquisidores alegou que somente se uma mulher introduzisse o "sêmen" no ânus de outra, por meio de um instrumento, ficaria caracterizada a sodomia, estando os demais atos no domínio das molícies. Na defesa dessa posição se alegava a impropriedade do "vasanterius" para a consumação do crime, por ser a vagina o vaso natural. Contudo, houve um deputado que, mesmo considerando esse caso "gravíssimo", recomendava que não se delegasse à jurisdição do Santo Ofício "o conhecimento penoso dessas torpezas". A segunda posição, defendida pelo inquisidor Mateus Homem Leitão, alegava que à Inquisição só cabiam os casos de pro príssima sodomia (penetração fálica no ânus com derramamento de sêmen); se o Santo Ofício tomasse conhecimento de penetrações com "falsos membros", fossem dedos ou falos artificiais (de vidro, madeira, cerâmica, couro ou qualquer outra matéria), teria também que julgar "vasos falsos" (quando alguém usava as mãos ou a boca como receptáculo à ejaculação) o que, a seu ver, não teria cabimento (VAINFAS, 1986-1987, p. 237-239; VAINFAS, 2014, p. 268-269).

Enfim, posicionou-se o deputado D. Veríssimo de Lencastre, a quem pareceu que todos os atos cometidos por mulheres, com ou sem uso de instrumento, fossem no ânus ou na vagina, eram nefandos e, portanto, sujeitos à Inquisição. Sem dúvida, D. Veríssimo foi o juiz mais rigoroso, mas também foi o único a conceber, ainda que em esboço, uma noção de homossexualidade extensiva às mulheres. Todavia, não foi a opinião que prevaleceu. Os demais inquisidores mostraram-se indiferentes ao homoerotismo feminino, retirando-lhe toda e qualquer importância. "Negaram a sodomia entre mulheres pela ausência do [pênis] ou só a admitiram com a presença de instrumentos fálicos capazes de transmitir 'sêmen' de uma mulher ao ânus da outra". Diante do impasse, a 22 de maio de 1646, o Conselho Geral reconheceu não ter jurisprudência no assunto; decidiu então que nada faria para resolver 
a questão até que houvesse um pronunciamento do Romano Pontífice (VAINFAS, 1986$1987 ; 2014){ }^{1}$

Tanto Luiz Mott (2006, p. 255) quanto Lígia Bellini (2014, p. 98) interpretam essa decisão do Conselho Geral - de "suspender" ou "renunciar" de sua jurisdição a sodomia foeminarum - equivalente à "descriminalização do lesbianismo em Portugal". Ronaldo Vainfas (2006, p. 277, nota 125), entretanto, acredita ser uma conclusão apressada, pois casos escandalosos desse tipo continuavam na alçada da justiça secular. O certo é que a decisão inquisitorial de "renunciar" a seu foro os casos de lesbianismo não significa necessariamente "descriminalização", pois eram diversas as instâncias judiciárias passíveis de julgar transgressões desse jaez à época.

No final do século XVII, a sodomia foeminarum inquietou profundamente o clérigo italiano Luigi Maria Sinistrari, que lamentava o fato de ninguém explicar de que forma as mulheres pecavam no nefando. Sinistrari escreveu um tratado sobre o assunto que foi publicado em Roma, no ano de 1700, sob o título "De sodomia". Nele estão referidas e ordenadas, segundo a gravidade, as práticas consideradas ilícitas no campo do homoerotismo feminino, conforme a ótica do autor. De acordo com Sinistrari, o corpo da mulher produzia esperma que "caído dos testículos é ejaculado pelos sopros seminais dentro do útero, lugar que a natureza fixou para que se aloje e, misturado ao esperma do homem, engendre o feto". Assim, estando duas mulheres deitadas, "uma íncuba e outra súcuba", é possível que "o sêmen da íncuba penetre dentro do vaso da súcuba". Ademais, continua o autor, "no corpo feminino se encontra uma parte que os anatomistas chamam de 'clitóris'. Esta parte é composta dos mesmos elementos que o pênis do homem [...] o clitóris é inflado pelo movimento dos sopros seminais. Ele é provido [...] de uma glande; em cima da glande há um orifício que, entretanto, não se percebe" (apud BELLINI, 2014, p. 41-46).

Sinistrari ainda explica que o clitóris "é o órgão da deleitação" feminina; existe em todas as mulheres, mas nem todas o possuem "descoberto ou o fazem sair para fora do vaso do pudor". Nalgumas regiões da África, segundo o clérigo, as mulheres "têm o clitóris saliente, ele pende como um pênis e é costume, quando nascem meninas, de lhes queimar o clitóris com um ferro em brasa para impedir seu crescimento exagerado". Na Europa, ao contrário, não são desenvolvidos, exceto nas mulheres que "por abundância de calor e de sêmen, possuem sopros seminais vigorosos que inflam o clitóris" e as que na infância "se tocam [nas] partes genitais sob o estímulo de precoces desejos. Entre algumas mulheres 0 clitóris é do tamanho do dedo médio da mão; entre outras é maior". Na visão do religioso, só ocorreria sodomia foeminarum quando uma mulher, com o seu clitóris, penetrasse a outra - ainda que não houvesse "seminação". Portanto, era abandonada a questão do "vaso impróprio e do derramamento de sêmen". A posse de um clitóris mais desenvolvido passava a constituir uma prova do crime. Os demais atos sexuais, inclusive com o uso de falo inanimado, pertenciam ao campo das molícies e assim deveriam ser tratados (BELLINI, 2014, p. 46-49).

No que concerne à pena capital, a última condenação na Europa ocorreu na Saxônia, que então integrava o reino da Prússia. Em 1721, Catharina Margaretha Linck foi executada. Catharina assumiu a persona masculina, serviu como soldado em vários exércitos, casou-se duas vezes com a mesma mulher, Margaretha Mühlhahn, a primeira na lgreja Luterana e a segunda na forma tridentina (o que fizera por conveniência pessoal). Usava um pênis de

' Paradoxalmente, o Regimento inquisitorial de 1774 manteve as mesmas punições (açoites e degredo) às mulheres "compreendidas em sodomia". Para Vainfas (2014, p. 275, nota 65$)$, a manutenção do § 13, tít. XXV, do Regimento de 1640, visava somente às mulheres implicadas em sodomia imperfeita (heterossexual), jamais em atos lésbicos - abandonados pelo Conselho Geral em 1646. 
couro (atado à cintura) nas relações sexuais com sua "esposa". Obrigava Margaretha a beijá-lo, sugá-lo e, por usá-lo fartamente, chegou a ferir sua amante - assim como a outras mulheres alhures. Presas em Halberstadt, Catharina e Margaretha foram julgadas (com o recurso da tortura) e consideradas culpadas de sodomia. A sentença de morte imposta a Linck teve de ser confirmada pelo rei Frederico Guilherme I. Foi decapitada e seu corpo, posteriormente, queimado. Quanto à Mühlhahn, recebeu como castigo três anos de prisão, seguidos de expulsão da cidade (BRAGA, 2011, p. 10-11; VAINFAS, 2014, p. 210; 348).

O Santo Ofício português, no entanto, jamais executou alguma mulher por crime de sodomia foeminarum. Além dos casos mencionados até aqui, mais duas mulheres foram queimadas na França durante o século XVI; enforcou-se outra na ltália (1580); queimou-se uma na Suíça (1568) e, até mesmo na Rússia ortodoxa, por volta de 1645, há notícias de mulheres queimadas vivas por sodomia (VAINFAS, 2014, p. 380). É, portanto, do mundo de mulheres reais que este texto se ocupa. Mulheres que, movidas por múltiplos desejos, e não poucas razões, desafiando os padrões morais estabelecidos, vivenciaram relações homoeróticas (VAINFAS, 1997, p. 116). Numa época em que não havia direitos humanos, arcaram com as consequências de suas escolhas: afogamento, enforcamento, decapitação, confisco, fogueira, suplícios, açoites e degredos - eis os castigos que a Europa cristã destinava às mulheres nefandas na Época Moderna.

\section{Um delito discreto}

A Inquisição lusa, efetivamente, processou poucas mulheres por sodomia foeminarum. Alguns casos que desvelam certo homoerotismo feminino foram julgados por outros crimes. Dentre eles, encontra-se o das freiras Maria do Espírito Santo (24 anos) e Camila de Jesus (23 anos). Em 1574, no mosteiro de Santa Marta de Lisboa, as religiosas mantiveram por seis meses uma relação erótica. A mais velha, dizendo ter recebido numa visão celestial ordem para ser "mãe espiritual" da Irmã Camila de Jesus, e sentindo "o peito cheio de grandezas e bens de Deus", dava de mamar à sua "filha espiritual". Amamentação místico-erótica que, descoberta pelo confessor, levou as religiosas às barras do Santo Ofício. No entanto, foram sentenciadas por proposições heréticas, não havendo menção ao pecado nefando (MOTT, 1987, p. 32). Respectivamente em 1659 e 1719, outras duas freiras - Joana da Cruz (em Lisboa) e Joana Maria de Jesus (em Vizeu) - foram processadas por supostas visões, revelações e outros delírios místicos. Ambas, entre as várias culpas registradas, tinham experimentado relações sexuais com outras mulheres. Entretanto, as duas também foram sentenciadas por proposições heréticas e não por atos sodomíticos (BELLINI, 2014, p. 96).

A Igreja sempre fora escrupulosa com questões místicas e revelações espirituais. Os eruditos juízes da fé inquiriam os supostos videntes para averiguar se tais arrebatamentos, êxtases e visões eram frutos "extraordinários do favor de Deus", ou se eram invenções humanas para "sua própria glória". Se as visões fossem verdadeiras, restava ainda descobrir se eram provenientes de Deus ou do Diabo, tarefa nada fácil (Geraldo PIERONI, 2006, p. 207, 210). Caso extraordinário ocorreu na Itália, na primeira metade do século XVII, quando a Irmã Benedetta Carlini, abadessa do convento da Mãe de Deus, dizia receber mensagens sobrenaturais e ter visões de anjos e santos, inclusive do próprio esposo místico - Jesus. Sua fama de santidade ultrapassou os muros do convento e, por duas vezes, os juízes eclesiásticos estiveram na pequena cidade de Pescia (próxima à Florença), para examinar seus estigmas e estudar o conteúdo de suas visões.

Benedetta Carlini foi destinada à vida religiosa desde o nascimento, considerado "milagroso". Aos 9 anos de idade entrou no convento das freiras teatinas de Pescia e foi eleita abadessa em 1620, aos 30 anos (algo raro à época). Tudo mudou quando, aos 23

6 Revista Estudos Feministas, Florianópolis, 26(3): e48787 
anos, Benedetta passou a ter experiências místicas, visões e colóquios espirituais (aparentemente bons e ingênuos). Seus superiores, sobretudo seu confessor (Paolo Ricordati), Ihe aconselharam a não acreditar em nada do que visse, desencorajando-a a entrar em transe. Aos 25 anos a religiosa começou a sofrer dores tão intensas que, frequentemente, ficava paralisada. Seu sofrimento físico foi atribuído à pressão dos superiores para abandonar os êxtases - conflitos psicológicos mal resolvidos que desencadearam sintomas somáticos. Sofreu silenciosamente, só no claustro, por quase dois anos, até que as visões recomeçaram e, durante o sono, demônios lhe afligiam para que abandonasse a vida religiosa. Em diversas madrugadas Benedetta gritava por socorro, ao que designaram a Irmã Bartolomea Crivelli para ajudá-la nas batalhas contra o Diabo. Passaram a compartilhar a mesma cela e, a partir de então, entre prolongados êxtases espirituais, Benedetta ("invadida" pelo anjo Splendittelo) vivenciou uma intensa relação homoerótica com Bartolomea, por quem demonstrava, para além de um impetuoso desejo sexual, um amor delicado e terno (BROWN, 1987, passim).

Já em Portugal, em 1787, numa devassa feita por ordem do arcebispo de Braga, D. Gaspar de Bragança, no mosteiro de São Bento de Viana do Castelo, segundo denúncias de várias religiosas, a madre Maria Josefa de Santa Teresa (39 anos) dormia constantemente com Josefa Ventura do Sacramento (27 anos) e com D. Maria Rosa (46 anos). Conforme o testemunho das religiosas, Maria Josefa perturbava a paz no mosteiro, "ora dorme com uma, ora com outras; ora na sua cela, ora nas delas; tendo [...] zelos umas das outras". O suposto triângulo amoroso gerou certo ciúme em Maria Josefa, que chegou a agredir Maria Rosa por dar mais atenção à Josefa Ventura. O comportamento da madre causava grande escândalo, sendo que, além de tudo isso, proferia palavras torpes e obscenas (BRAGA, 2011 , p. 35-36). Ao que parece, os conventos eram habituais espaços de paixões nefandas. Todavia, os autos que a partir de agora iremos analisar pertenceram ao processo de uma jovem casada, Clara Fernandes, residente em Lisboa que, em 1555, procurou a Mesa da Inquisição para confessar suas experiências ilícitas. Ancorado em Michel Foucault, Durval Muniz de ALBUQUERQUE JÚNIOR $(2007$, p. 137, 139) pontifica que cada experiência é única e só existe como prática enquanto se dá em ato. Ela se atualiza a cada acontecer e de nova forma, produz efeitos imediatos e se esgota. Não deixa sementes, deixa ramificações, não conduz substância, mas intensidade. Fazer história da experiência não significa fazer história do concreto em si, de objetos e sujeitos já dados, preexistentes à documentação que os nomeia, mas investigar o que possibilitou que aquela experiência aflorasse e fosse registrada como tal. A experiência - continua o historiador - não é uma voz do passado que foi esquecida e precisa ser salva, é uma "fissura no silêncio", silêncio a que está condenada a maior parte dos seres humanos. O que se deve perguntar ao documento não é apenas o que diz essa voz que rompeu o silêncio do passado, mas por que ela pode romper esse silêncio, que condições históricas permitiram que essa experiência não permanecesse sepultada no passado.

Nessa perspectiva, tentaremos desvendar que condições históricas permitiram que as experiências de Clara Fernandes causassem certa "fissura no silêncio" e não permanecessem sepultadas no passado. Era o dia 6 de julho de 1555, na Casa do Despacho da Santa Inquisição, quando Clara - atormentada por experiências vividas na noite anterior - pediu audiência na Mesa. Foi atendida por Ambrósio Campelo, deputado inquisitorial e membro do Desembargo do Paço. Clara apresentou-se dizendo ter entre 23 ou 24 anos, casada com Francisco Fernandes (mourisco) e que ganhava "sua vida a lavar roupas". Após o juramento dos santos evangelhos, em que prometeu dizer a verdade, confessou que: 


\begin{abstract}
Jazendo ontem na cama de noite em casa de D. Inácio com uma Catariana da Rosa, mulher branca, casada com Damião Mendes, [...] a qual é mulher moça, e ouviu dizer que [teria] 18 [...] ou 17 anos e jazendo assim na cama sós, ela Clara Fernandes, pecou em beijar e abraçar e apalpar a dita mulher pondo-se ela declarante em cima da outra como um homem em cima de uma mulher e isto por uma vez, porém que o beijar e abraçar foi por muitas vezes na dita noite enquanto estiveram acordadas e o mesmo, apalpar e beijar e abraçar, fazia a dita Catariana da Rosa a ela declarante, de maneira que ela cumpriu com a dita Catariana da Rosa, como um homem com uma mulher, e a dita Catariana da Rosa lhe disse que fizera o mesmo naquele ato e que ninguém sabe disso por que faziam sós (ANTT, IL, proc. 12.418, fls. 2-2v [grifo meu]).
\end{abstract}

Ambrósio Campelo estava diante de um caso de sodomia foeminarum. Em tese, o Santo Ofício ainda não tinha jurisdição sobre atos nefandos praticados por mulheres. Como visto, foi apenas no Regimento de 1640 que tal competência foi mencionada. Por ocasião do relato de Clara, o Tribunal já contava com uma provisão de D. João III, datada de 10 de janeiro de 1553, e outra do cardeal D. Henrique (inquisidor-geral), datada de 24 de maio de 1555, as quais autorizavam o Santo Ofício a conhecer casos de sodomia (ANTT, IL, INDEX DOS REPERTÓRIOS DO NEFANDO, 143-7-44, fl. 1v). Entretanto, ao que parece, tais provisões se referiam apenas à sodomia masculorum. No caso em análise, a sodomia foeminarum era crime sob competência da justiça secular, pois a Determinação Régia de D. Manuel (1499) e as Ordenações Manuelinas (1512) estabeleceram a pena de morte na fogueira às culpadas.

Conhecedor dessa legislação, posto que além de deputado inquisitorial era membro do Desembargo do Paço, por que motivo Ambrósio Campelo não transferiu o caso de Clara Fernandes para a justiça civil? Não seria a atitude mais sensata a ser tomada? Uma resposta exata, obviamente, a documentação não oferece. Todavia, é plausível conjecturar que talvez o deputado não desejasse ver aquela infeliz mulher arder na fogueira. Afinal, Clara buscou voluntariamente a Inquisição para confessar suas culpas, o que sugere um sinal de arrependimento. O certo é que Ambrósio Campelo não declinou do caso, ao contrário, acolheu a confissão na Mesa do Santo Ofício.

Clara continuou relatando que (também na noite anterior) Catarina da Rosa, numa conversa com amigos, acabou deixando escapar que ambas praticavam atos nefandos, o que sugere que não dormiram juntas somente uma vez. Talvez Clara, sentindo-se ameaçada, preferiu procurar a Mesa da Inquisição antes de ser denunciada, o que, certamente, seria pior. E prosseguiu dizendo que

[há] um ano que ela pecou da mesma maneira com uma Isabel Mendes, mulher moça que está em casa de sua mãe que se chama Margarida Gonçalves [...] a qual Isabel Mendes diz que é casada com um músico do Infante que se chama Barbosa, [...] jazendo ela declarante com a dita Isabel Mendes uma noite sós ambas na mesma cama [...] se apalparam e beijaram e abraçaram uma a outra até que ela confessante se pôs em cima dela, e cumpriu com ela como um homem com uma mulher, e a dita Isabel Mendes lhe disse que fizera o mesmo, e isto uma vez somente e que nunca mais com ela pecou nem antes, nem depois, [...] e que do pecado que cometeu com a dita Isabel Mendes se confessou já a seu confessor e fez a penitência (ANTT, IL, proc. 12.418, fls. 2v-3v).

O deputado, escandalizado com a nova revelação, parece duvidar se estaria mesmo diante de uma mulher. Seria Clara Fernandes uma anomalia da natureza? Atordoado por pensamentos similares, Ambrósio Campelo chegou ao extremo de perguntar se Clara realmente era mulher, ao que a mesma respondeu positivamente: "tinha senão natura de mulher e que tem três filhos que pariu, e que promete de nunca mais ofender a Nosso Senhor Jesus Cristo [nesse] pecado". Foi ordenado que guardasse "segredo no que disse e que se 
confessasse"; além da penitência do confessor, "que jejuasse duas sextas-feiras a pão e água" e mais penitências espirituais até a festa de Nossa Senhora de Agosto. Por fim, "que não dormisse em cama com mulher alguma senão sendo extrema necessidade". Clara tudo prometeu cumprir e, por não saber assinar, rogou ao notário (Emanuel Cordeiro) que assinasse por ela.

No entanto, a jovem não teve tempo de cumprir suas penitências. Quatro dias depois, a 10 de julho de 1555, foi entregue ao alcaide Brycio Camelo, para ser presa no cárcere da Santa Inquisição. Já no dia seguinte, foi levada pelos guardas à presença do inquisidor Leonardo Alves de Paredes e admoestada a fazer uma nova confissão. Apavorada, iniciou dizendo que tinha 25 anos de idade e que há "três anos que [...] usa do mau pecado, tendo acesso com mulheres". Com uma certa Catarina do Avelar, "que é muito moça e gentil mulher", por espaço de um mês, juntaram suas "naturas uma com a outra e esfregando uma com a outra, como faz um homem com uma mulher, e assim cumpriram ambas". Também com Margarida Mendes, por 5 ou 6 vezes, tiveram "acesso carnal" e com Isabel Mendes, não foi uma vez apenas, mas duas. Em todas as relações sexuais, Clara sempre atuava como íncuba.

Chama atenção nos autos a falta de detalhes sobre o que realmente Clara Fernandes e suas parceiras faziam na cama; os ministros inquisitoriais limitaram-se a mencionar: beijos, abraços e carícias. Reproduziram o modelo arcaico do sexo "homem sobre a mulher", Clara sempre "por cima", quando esfregavam suas vaginas até "cumprirem". Os registros são tão evasivos que poderíamos pensar que tais amantes (apesar da "culpa" que sentiam por praticarem atos interditos) não desfrutaram da plenitude do prazer sexual, não fosse o notário observar que sempre "cumpriam" - o que equivale a dizer que atingiam o orgasmo. Nada do que foi descrito nos autos se aproxima das anotações que os juízes eclesiásticos fizeram no caso da nossa já conhecida Benedetta Carlini com Bartolomea Crivelli.

Quando Bartolomea se aproximava, Benedetta agarrava-a pelo braço e a atirava sobre a cama. Abraçando-a, beijava-a como se fosse um homem, falando-lhe palavras de amor, ficava se mexendo em cima de Bartolomea até que ambas se "corrompiam". E assim, por duas, às vezes três horas, ficavam juntas. "Seja minha de todo o seu coração e de toda a sua alma e deixe-me fazer o que eu quiser, que eu lhe darei todo o prazer que desejar" sussurrava o anjo Splendittelo pelos lábios da abadessa. Além de inúmeros atos lascivos, tais como beijos que Benedetta dava nos seios de Bartolomea, ambas praticavam masturbação mútua até atingirem o orgasmo. Algumas vezes a abadessa colocava o dedo da amante em seus genitais e "mantendo-o lá [...] ficava se mexendo até se corromper a si mesma". Noutras ocasiões metia o dedo na vagina da companheira "e a corrompia". Por mais de dois anos (noite ou dia), pelo menos três vezes por semana, pecavam no nefando. Na maioria das vezes, se despiam e cerca de vinte vezes Benedetta beijou os genitais de Bartolomea. Quando a amante se recusava a manter relações sexuais com a abadessa, Benedetta masturbava-se diante de Bartolomea até "se corromper" (BROWN, 1987, p. 169-174).

Freiras lésbicas à parte, poucos dias volvidos, Catarina da Rosa (esposa do alfaiate Damião Mendes) procurou a Mesa da Inquisição para confessar suas culpas. Relatou que, por duas vezes, teve relações sexuais com Clara Fernandes, mulata forra, prisioneira no cárcere do Santo Ofício e que nunca ficou "por cima" da parceira, por estar grávida e "haver medo de perigar a criança". Dentre outras coisas, revelou que corria a fama de que Clara, por muitas vezes, dormira com uma moça que usava uma saia roxa "cujo nome não sabe" e que a própria mulata havia lhe confidenciado sua grande paixão, uma moça que usava saia branca, cujo nome não the disse, esta sim "a matava e a quem ela queria bem". Ao que parece, Clara teve diversas parceiras, mas a uma só "amava". Ademais, ao arcar com as consequências de suas escolhas, foi submetida a um procedimento sumário. 
Após suas confissões e a denúncia de Catarina da Rosa, o processo não teve nenhum outro rito, constando apenas a lavratura do acórdão:

Os inquisidores e deputados da Santa Inquisição com comissão d'El-Rei Nosso Senhor, neste caso, [...] que vistos estes autos e como por eles e confissão da ré Clara Fernandes, mulher baça, forra e casada, moradora nesta cidade, se mostra ela com mui grande atrevimento e sem temor de Deus, cometer por muitas e diversas vezes e por muito espaço de tempo o nefando e abominável pecado de sodomia contra natura com outras mulheres, sendo ela ré a agente no dito mau pecado e provocando as outras a cometerem, o que tudo visto e a qualidade e graveza do dito crime e continuação dele com o mais que dos autos consta, condenam a dita ré Clara Fernandes a cárcere perpétuo, estreito e apartado, no qual estará [por] todos os dias de sua vida e será açoitada no dito cárcere, e às sextas-feiras jejuará a pão e água, em penitência de tão graves ofensas que cometeu contra Nosso Senhor, e será instruída nas coisas necessárias para sua salvação, e confiscação [de] todos os seus bens se os [tiver], para a Coroa do Reino, vista a disposição do Direito no caso (ANTT, IL, proc. 12.418, fls. 9).

Clara ouviu sua sentença na Mesa, a 29 de janeiro de 1556, proclamada pelo frei Jerônimo de Zambuia, estando presente na sala da Inquisição o seu marido, Francisco Fernandes. Aliás, esta é a única menção que o notário faz sobre o marido da ré e nada consta na documentação sobre os seus filhos. Terminada a leitura do acórdão, Clara foi conduzida pelos guardas a uma cela "estreita e apartada" nos cárceres inquisitoriais, para cumprir sua pena. Poucos dias depois, foi açoitada citra sanguinis effusionem. Acabado o suplício, desfalecida, os algozes se foram deixando-a só na cela, para se recompor. Ali deveria permanecer, até que a morte se apiedasse e viesse buscá-la.

Entretanto, os últimos papéis do processo trazem novas informações. Clara havia sido transferida para o cárcere do Colégio (que a fonte não revela o nome), a fim de ser "instruída na fé". Depois de quase cinco anos de pena, enviou missiva ao Santo Ofício implorando por liberdade. O redator da petição destacou que a ré "está muito bem doutrinada [nas] coisas de nossa santa fé católica" e "professa viver e morrer como verdadeira cristã". Clara suplicava a liberdade pela "paixão e morte de Nosso Senhor Jesus Cristo" e por "ser muito pobre e não ter outra coisa do que se manter senão das esmolas da Santa Misericórdia", que há um ano Ihe tiraram, estando a "padecer muita fome e necessidade" e por ter uma mãe com 70 anos de idade; "a queiram mandar soltar para a ajudar a sustentar sua velhice", visto que nos últimos cinco anos vem servindo a "doentes e sãos do dito cárcere, sem nenhum prêmio nem interesse", comprometendo-se a - "enquanto viver" - rogar a Deus pela vida dos senhores inquisidores.

Os juízes da fé não deixaram sua súplica sem resposta e, em 10 de dezembro de 1560, autorizaram que Clara fosse "solta" do cárcere do Colégio e transferida para o Hospital Real de Todos os Santos, devendo obedecer às ordens dos padres responsáveis pela instituição, e de lá "não sairá sem licença dos inquisidores pelo tempo que lhes parecer [...] para salvação de sua alma". Deverá, ainda, se confessar pela Páscoa e receber o Santíssimo Sacramento, de conselho com seu confessor, ouvir missas aos domingos e festas, comportando-se como uma boa cristã e apartando-se de todas as ocasióes de pecado. Após a deliberação inquisitorial, nada mais sabemos sobre o seu caso.

\section{Considerações finais}

Qual anamnese, o caso de Clara Fernandes evoca tantos outros que, por não terem deixado "rastros", são presumidos inexistentes. Ancorado em Foucault, e referindo-se aos indivíduos comuns, excluídos da História, Albuquerque Júnior (2007, p. 145) explica que, 
para que algo dessas existências chegasse até nós, foi necessário que um feixe de luz (ao menos por um instante) viesse iluminá-las. Luz essa que lhes vem do exterior. Aquilo que as arranca à noite em que elas poderiam, e talvez devessem sempre, ter ficado, é o "encontro com o poder". Sem esse choque, é indubitável que nenhuma palavra teria ficado para lembrar aquele fugidio trajeto. O poder que vigiou aquelas vidas, que as perseguiu, que as marcou com um golpe de suas garras, foi também o poder que suscitou as poucas palavras que delas nos restam. Todas aquelas vidas estavam destinadas a desaparecer, sem nunca terem sido ditas, senão em virtude do seu contato momentâneo com o poder.

Nessa perspectiva, o Tribunal que "puniu", ao mesmo tempo "iluminou"- ao menos por um instante - as sombras do esquecimento nas quais a jovem Clara estava destinada a permanecer. Simultaneamente, a Inquisição reprimia e registrava os únicos relatos que dela nos restam. Sem essa "colisão", certamente, Clara estaria condenada ao silêncio na História. Estaríamos, então, diante de um "recorte" exato do passado? Absolutamente. Partindo do pressuposto de que o historiador lida com existências reais, essas chegam até nós de forma fragmentária e mediada pelos discursos que, por sua vez, são produto de um determinado lugar e época. Esses documentos são fragmentos do real, não por nos ser possível (através deles) reaver "pedaços" do passado, do real em si, mas por terem nele atuado, terem participado da construção da realidade, quase sempre trágica, desses indivíduos. Os documentos são testemunhos "de um esmagamento pelo poder", são expressão de uma revolta que não pode ter deixado nada (salvo breves palavras trocadas com o poder), mas podem ter sido a liberdade momentânea de indivíduos perante códigos que se tornaram insuportáveis (ALBUQUERQUE JÚNIOR, 2007, p. 145-146). Por certo, casos como o de Clara Fernandes são uma recordação amarga dos excessos em defesa do que se considerava a verdade, no entanto, também são vestígios de inobservância, de desobediência face ao poder; indícios de mulheres comuns que procuraram dar respostas aos apelos da sexualidade, praticando atos "interditos" e afrontando os guardiões da licitude.

\section{Referências}

ALBUQUERQUE JÚNIOR, Durval Muniz de. História: a arte de inventar o passado. Ensaios de Teoria da História. Bauru: EDUSC, 2007.

ARQUIVO NACIONAL DA TORRE DO TOMBO, INQUISIÇÃO DE LISBOA: Processo 12.418; Index dos Repertórios do Nefando, 143-7-44.

BELLINI, Lígia. A coisa obscura: mulher, sodomia e Inquisição no Brasil colonial. Salvador: EDUFBA, 2014.

BLUTEAU, Raphael. Verbete Nefando. Vocabulario Portuguez e Latino. Coimbra - 1728. Disponível em: http://dicionarios.bbm.usp.br/pt-br/dicionario/1/nefando. Acesso em: 08/ $12 / 2016$.

BRAGA, Paulo Drumond. Filhas de Safo - uma história da homossexualidade feminina em Portugal (séculos XIII-XX). Lisboa: Texto Editores, 2011. Livro digital (2016).

BROWN, Judith. Atos impuros: a vida de uma freira lésbica na Itália da Renascença. São Paulo: Brasiliense, 1987.

CODIGO PHILIPPINO, OU, ORDENAÇÕES E LEIS DO REINO DE PORTUGAL: RECOPILADAS POR MANDADO D'EL-REY D. PHILIPPE I. "Dos que cometem pecado de sodomia e com alimárias", liv. V, tít. XIII. Rio de Janeiro: Typ. do Instituto Philomathico, 1870.

ENGEL, Magali. "História e sexualidade". In: CARDOSO, Ciro Flamarion; VAINFAS, Ronaldo (Org.). Domínios da História: ensaios de teoria e metodologia. Rio de Janeiro: Campus, 1997. p. 430-450. 
EPÍSTOLA AOS ROMANOS. In: BÍBLIA SAGRADA. Tradução dos originais mediante a versão dos Monges de Maredsous (Bélgica) pelo Centro Bíblico Católico. São Paulo, Ave-Maria, 1995.

FIGARI, Carlos. @s outr@s cariocas. Interpelações, experiências e identidades homoeróticas no Rio de Janeiro. Séculos XVII ao XX. Belo Horizonte: EDUFMG; Rio de Janeiro: IUPERJ, 2007.

GOMES, Verônica de Jesus. Atos nefandos: eclesiásticos homossexuais na teia da Inquisição. Curitiba: Prismas, 2015.

MOTT, Luiz. "A revolução homossexual: o poder de um mito". Revista USP, n. 49, p. 40-59, março/maio 2001. O lesbianismo no Brasil. Porto Alegre: Mercado Aberto, 1987.

O sexo proibido: virgens, gays e escravos nas garras da Inquisição. Campinas: Papirus, 1988.

. "Sodomia não é heresia: dissidência moral e contracultura". In: VAINFAS Ronaldo; FEITLER, Bruno; LIMA, Lana Lage da Gama (Org.). A Inquisição em Xeque: temas, controvérsias, estudos de caso. Rio de Janeiro: EDUERJ, 2006. p. 253-266.

ORDENAÇÕES MANUELINAS (1512). Dos que cometem pecado de sodomia, liv. V, tít. XII. Disponível em: http://www1 .ci.uc.pt/ihti/proj/manuelinas/ordemanu.htm. Acesso em: 20/ $12 / 2016$.

PIERONI, Geraldo. "Ad discernendas veras a falsis visionibus et revelationibus: a Inquisição e as falsas visões de Maria Dias, degredada para o Brasil". In: VAINFAS, Ronaldo; FEITLER, Bruno; LIMA, Lana Lage da Gama (Org.). A Inquisição em Xeque: temas, controvérsias, estudos de caso. Rio de Janeiro: EDUERJ, 2006. p. 205-212.

REGIMENTO DO SANTO OFÍCIO DA INQUISIÇÃO - 1640. Liv. III, tít. XXV, § 13. Revista do Instituto Histórico e Geográfico Brasileiro, Rio de Janeiro, ano 157, n. 392, p. 693-883, jul./set. 1996.

VAINFAS, Ronaldo. "Homoerotismo feminino e o Santo Ofício". In: DEL PRIORE, Mary (org.). História das mulheres no Brasil. São Paulo: EDUNESP, 1997. p. 115-140.

"Inquisição como fábrica de hereges: os sodomitas foram exceção?". In: VAINFAS, Ronaldo; FEITLER, Bruno; LIMA, Lana Lage da Gama (Org.). A Inquisição em Xeque: temas, controvérsias, estudos de caso. Rio de Janeiro: EDUERJ, 2006. p. 267-280.

"Sodomia, mulheres e Inquisição: notas sobre sexualidade e homossexualismo feminino no Brasil colonial". Anais do Museu Paulista. Tomo 35, USP, p. 231-249, 19861987.

Trópico dos pecados: moral, sexualidade e Inquisição no Brasil. Rio de Janeiro: Civilização Brasileira, 2014.

[Recebido em 31/01/2017, reapresentado $11 / 11 / 2017 \mathrm{e}$ aprovado em 03/04/2018]

Incarcerated by Homoerotism: Clara Fernandes, a Lesbian before the Inquisition Court

Abstract: In the Portuguese society of the Old Regime, sex between women was susceptible to the death penalty at the stake and, as a mixed crime, was also under the jurisdiction of the Inquisition Tribunal. The objective of this study is to analyze the inquisitorial process of the young Clara Fernandes sentenced, in 1556, by sodomy foeminarum. Although married and the mother of three children, Clara's attitudes express an unconstrained sexual desire for women. Tormented by her "guilts" sought pardon of the Holy Office, but found the "justice" of an inclement Tribunal. Keywords: Inquisition; Sodomy foeminarum; Repression

12 Revista Estudos Feministas, Florianópolis, 26(3): e48787 
Ronaldo Manoel Silva (ronaldomsrt@hotmail.com) possui Graduação em Licenciatura em História (2009), Especialização em História do Brasil (2015). Atualmente é mestrando em História (Linha de Pesquisa: Política, Instituições e Identidades) pela Universidade Federal Rural de Pernambuco. É autor de Raízes da Intolerância: Inquisição e sodomitas em Pernambuco colonial (1593-1595). Brasília: Senado Federal, 2016. Investiga a repressão inquisitorial às minorias sexuais no Antigo Regime português.

(iD) $0000-0002-5176-812 X$ 